\title{
The Rise and Development of Lexicography \& Dictionary Craft in Tiechiu-Swatow Dialect during Late Qing Dynasty
}

\author{
Hai Wang ${ }^{1}$, \& Daiming Huang ${ }^{2}$ \\ ${ }^{1}$ Professor, School of Journalism \& Communication and School of Interpreting \& Translation Studies in Guangdong \\ University of Foreign Studies, Guangzhou, China \\ ${ }^{2}$ School of Journalism \& Communication in Guangdong University of Foreign Studies, Guangzhou, China \\ Correspondence: Wang Hai, School of Journalism \& Communication and School of Interpreting \& Translation \\ Studies in Guangdong University of Foreign Studies, Baiyundadao, North No.2, Guangzhou, China.
}

\author{
Received: March 3, $2020 \quad$ Accepted: March 24, $2020 \quad$ Online Published: March 26, 2020 \\ doi:10.5430/wjel.v10n1p38 URL: https://doi.org/10.5430/wjel.v10n1p38
}

\begin{abstract}
In the first half of the 19th century, the Christian churches of Britain and America successively sent missionaries to the southeast Asia. American Baptist missionaries William Dean and Josiah Goddard, who preached in Bangkok, published First Lessons in the Tiechiw Dialect 1841 and A Chinese and English Vocabulary in the Tiechiu Dialect in 1847. They started the activities of missionaries and foreigners in China to compile dictionaries of Tiechiw-Swatow dialects. After the second Opium War, missionaries went deep into the hinterland of China, and the activities of compiling dictionaries of Chinese dialects became more active. The compilation techniques such as content design, Roman pronunciation scheme and tone annotation, and Chinese-English comparison, became more perfect. From the 1870s to 1911, foreign missionaries in Tiechiw-Swatow area compiled and published nine dictionaries. The purpose of this paper is to sort out the compilation process of Tiechiw-Swatow dialect dictionaries in the late Qing dynasty and the recognition of the regularity of compilation techniques, so as to provide reference for the study of compilation techniques of Tiechiw-Swatow dialect dictionaries and the dissemination of Tiechiw-Swatow regional culture in the English world.
\end{abstract}

Keywords: the Protestant missionary in China, lexicography \& dictionary in Tiechie-Swatow dialect, lexicography explanation, lexicography and dictionary craft

\section{Introduction}

In the first half of the 19th century, religious circles in western countries carried out the Great Awakening Movement. On September 4, 1807, Robert Morrison, a London missionary, arrived in Macau and then moved to Canton. The policy of "self-seclusion" implemented by the Qing court prohibited the spread of Christianity in China, which made Robert Morrison's preaching difficult. At the end of 1814, Robert Morrison and his assistant William Milne were forced to establish a mission station and an Anglo-Chinese college in Malacca near Canton. At the same time, they proposed Ultra Ganges Missionary Union to the London Missionary society (Milne, 1818(5):170-176). In order to facilitate missionary work, Protestant missionaries in China established Chinese and English newspapers and compiled English and Chinese dictionaries and textbooks, which became an important part of the project. The board of the London mission appointed Robert Morrison to go to China with the primary objective of mastering the Chinese language, translating the Bible into Chinese and compiling a Chinese-English dictionary (Mrs. Morrison, 2004:18). During his stay in China, Robert Morrison wrote Dictionaries of the Chinese Language, A Grammar of the Chinese Language, Vocabulary of the Canton Dialect and other dictionaries. From the beginning of the 19th century to the end of the Qing dynasty, nearly 70 Chinese-English bilingual dictionaries of various categories and sizes were compiled and published, mainly by western missionaries, supplemented by a small number of lexicographers from secular westerners and Chinese intellectuals (Yuan Qing, 2013(1):94 ).

In the first half of the 19th century, western missionaries concentrated their efforts on preaching to Siam, Myanmar and other southeast Asian regions and countries. The missionaries not only preached among the local people, but also carried out missionary activities among the Chinese immigrant communities in southeast Asia (Joseph Tse-Hei Lee, 2010: 37-195). The vast majority of Chinese in southeast Asia come from coastal areas such as Kwangtung, Fukien and Chekeäng. In order to communicate and carry out missionary activities with Chinese speakers of Cantonese, Published by Sciedu Press 
Teochew, Fukien and Ningpo dialects, Protestant Christian missionaries in China inherited the practice of using Latin as phonetic symbols for Chinese characters by Catholic priests Matteo Ricci and Nicalas Trigault, who came to China in the Ming dynasty. They tried to use Romanization in Chinese-English dictionaries or newspapers to spell Cantonese, Tiechiw-Swatow, Ningpo and Fukien dialects.

From the beginning of the 19th century to 1867, Protestant missionaries in China compiled and published more than 10 dictionaries of Cantonese, Tiechiw-Swatow, Ningpo and Fukien dialects (Alexander Wylie, 2011:9-299). These dictionaries innovated the Romanization scheme of Chinese dialects and became the basis of later Wade-Giles Romanization and Chinese postal map Romanization, laying a foundation for the overseas spread of Chinese phonetic scheme and Chinese and its dialects.

List of dictionaries of Cantonese, Tiechiw-Swatow, Ningpo and Fukien dialects (1807-1867)

1. A Dictionary of the Chinese Language compiled by Robert Morrison (1815, 1822, 1823, Macau)

2. Vocabulary of the Canton dialect compiled by Robert Morrison (1828, Macau)

3. A Dictionary of the Hok-keen Dialect of the Chinese Language, according to the reading and colloquial idioms compiled by Walter Henry Medhurst (1832, Macau)

4. Translation of a Comparative Vocabulary of the Chinese, Corean, and Japanese Languages, compiled by Walter Henry Medhurst (1835, Batavia)

5. Dictionary of Favorlang Dialect of the Formosan Language, written in 1650 compiled by Walter Henry Medhurst (1840, Batavia)

6. Chinese and English Dictionary compiled by Walter Henry Medhurst (1842-1843, Batavia)

7. English and Chinese Dictionary compiled by Walter Henry Medhurst (1847-1848, Shanghai)

8. The Vocabulary of the Hok-keen Dialect compiled by Samuel Dyer (1838, Singapore)

9. Chinese Chrestomathy in the Canton dialect edited by Elijah Coleman Bridgman (1828, Macau)

10. Easy Lessons in Chinese compiled by Samuel Wells Williams (1842, Macau) Macau)

11. An English and Chinese Vocabulary, in the Court Dialect compiled by Samuel Wells Williams (1844,

12. A Tonic Dictionary of the Chinese Language in the Canton Dialect compiled by Samuel Wells Williams (1856, Canton)

The dictionary of Tiechiw-Swatow dialect compiled by missionaries in late Qing dynasty is an important branch of Chinese phonology and dialect dictionary compilation by missionaries and foreigners in China. In the 1830s and 1840s, the American Baptist church sent missionaries to the southeast Asia, and the Teochew people, who lived in Bangkok, controlled the trade between China and Siam at that time, and then controlled numerous enterprises in Hong Kong (Lai Liansan, 1997:56-66). In order to facilitate the communication and preaching between foreign missionaries and the Tiechiw-Swatow people living in southeast Asia, Hong Kong and Tiechiw-Swatow, the American Baptist missionaries William Dean and Josiah Goddard who preached in Bangkok published First Lessons in the Tie-chiw Dialect and A Chinese and English Vocabulary in the Tie Chiu Dialect in 1841 and 1847 respectively, which started the activities of missionaries and foreigners in China to compile a series of dictionaries of Tiechiw-Swatow dialects.

After the second opium war, missionaries in China went deep into the hinterland of China and became more active in compiling dictionaries of Chinese dialects. From the 1870s to 1911, missionaries in Tiechiw-Swatow area compiled and published eight dictionaries and textbooks which including An Index to William Dictionary in the Swatow dialect, 1878, First Lessons in the Swatow dialect, 1878, Pronouncing and Defining Dictionary of the Swatow Dialect Arranged According to Syllables and Tones, 1883, The English-Chinese Vocabulary of the Vernacular or Spoken Language of Swatow, 1883, Primary Lessons in Swatow Grammar (Colloquial), 1884, A Swatow Index to the Syllable Dictionary of Chinese by S. Wells Williams, and The dictionary of the Vernacular of Amoy by Carstairs Douglas, 1886, Manual of Swatow Vernacular, Part 1, 1907, The Swatow Syllabary with Mandarin Pronunciation, 1909.

In the late Qing dynasty, there were only two dictionaries of Tiechiw-Swatow dialect compiled by foreigners except missionaries in China or foreigners in Tiechiw-Swatow area. In 1877, Herbert Allen Giles, a Sinologist and former minister of the British consulate in Swatow, published the Handbook of the Swatow Dialect with a Vocabulary in 
Shanghai. In 1886, Singapore's straits colony's interpreter Lim Hiongseng has compiled A Handbook of the Swatow Vernacular. In addition, in 1881, John Campbell Gibson based on Handbook of the Swatow Dialect with a Vocabulary and Chinese-English dictionary of Vernacular or Spoken Language of Amoy, with the principal variations of the Chang-chew and Chin-chew dialects, has compiled the Elementary Lessons in the Swatow Dialect with a Vocabulary Reference to Dr. Douglas' Dictionary of the Amoy Vernacular. However, this dictionary has not been officially published.

Up to now, the research on Tiechiw-Swatow dialect dictionaries in the late Qing dynasty has been focused on the pronunciations and phonological comparison of textbooks and dictionaries, or on the repetitive compilation of Tiechiw-Swatow dialect dictionaries in the late Qing dynasty. Most studies have included Tiechiw-Swatow dialect dictionaries into the branches of Fukien dialect dictionaries or dialect textbooks, but there is no systematic discussion on Tiechiw-Swatow dialect dictionaries compiled by missionaries in China and the historical evolution of compilation techniques.

This paper examines the missionary activities in Tiechiw-Swatow area in the late Qing dynasty and the development of compiling dictionaries of Tiechiw-Swatow dialect. This paper makes a comparative analysis of Tiechiw-Swatow dialect dictionaries in different periods and pays attention to the compilation techniques and phonological sounds of Tiechiw-Swatow dialect dictionaries in different stages. Based on the historical background of the activities of the missionaries and foreigners in China in phonology and lexicography, this paper expounds the social and historical significance of the lexicography compiled by foreign missionaries in Tiechiw-Swatow dialect. The compilation process of Tiechiw-Swatow dialect dictionaries in the late Qing dynasty and the recognition of its regularity such as word label are sorted out to provide reference for the in-depth study of the compilation techniques of Tiechiw-Swatow dialect dictionaries and the dissemination of Tiechiw-Swatow culture in the English world.

\section{Historical Process of Missionaries Compiling Dictionaries of Tiechiw-Swatow Dialect}

As a branch of phoneticization and compilation of dialect dictionaries of missionaries and foreigners in China, the Tiechiw-Swatow dialect dictionary is also an important measure of the localization of missionary work in China, which is closely related to the missionary activities of missionaries in China in Tiechiw-Swatow region. Based on the in-depth missionary activities in Tiechiw-Swatow and the evolution of lexicographical compilation methods in Tiechiw-Swatow dialect, the lexicographical compilation activities of missionaries in China can be divided into three periods:

\subsection{The Early Period of Tiechiw-Swatow Dictionaries Compiled by Missionaries in China in the 1840s}

Tiechiw-Swatow area is located in the northeast of Guangdong province. The Lotus Mountain in the west separates it from the Pearl River Delta region. The phoenix mountain in the northeast serves as a natural barrier to the Hakka area. Tiechiw-Swatow region has a long history of trading with southeast Asia. Due to its proximity to the South China Sea, frequent natural disasters, dense population and uneven distribution of resources, most Tiechiw-Swatow people go to southeast Asia for business or farming. The teochew coast was the first stronghold of maritime trade between China and Siam in the early 19th century, followed by Fukien (Jennifer W. Cushman, 1975:19). Tiechiw-Swatow people are the largest dialect group of Chinese in Siam. The ancestors of Chinese immigrants in Bangkok are basically from Tiechiw-Swatow (Alexander Wylie, 2011: 92 ).

In 1829, Prussian missionary Karl Friedrich August Gützlaff resigned his post as the Netherlands Missionary Society and traveled to Singapore, Siam and Malacca (Alexander Wylie, 2011:60-61). Gützlaff realized the value of the Tiechiw-Swatow dialect groups in southeast Asia as targets of preaching. Due to the lack of support from European Christian organizations, he instead asked American Baptist Missionary Union (ABMU) to send more missionaries to China (Jessie G. Lutz, 1990: 46-77). In 1832, the ABMU sent John Taylor Jones to Siam to preach among the Tiechiw-Swatow immigrants. On July 2, 1834, William Dean and his wife departed from Boston for Siam aboard the Cashmere ship. In 1835, John Taylor Jones established the first Chinese Baptist church in southeast Asia in Bangkok and later became the general institution of the Chinese Baptist church in teochew. On October 16, 1840, ABMU sent missionary Josiah Goddard to Bangkok. In 1842, the Baptist mission moved from Bangkok to Hong Kong, and Josiah Goddard succeeded William Dean as pastor of the church. Rudolf Lechler, a Missionary from The Basel German Evangelical Missionary Society, entered Yanzao village, Chenghai district, Swatow city to preach in 1848. In fact, even before Rudolf Lechler, Karl Friedrich August Gützlaff visited Nanao island near the Chenghai district of Swatow twice in 1831 and in 1832 (Hu Weiqing, 2001(2): 337-358). Christian missionaries attacked the flanks of mainland China through the weak links of the Chinese community in southeast Asia (Barnett \& Fairbank,1985:13 ).

With the missionary activities of the American Baptist church among the Tiechiw immigrants in Siam, the 
compilation of dictionaries of Tiechiw-Swatow dialect became an important measure of missionary localization in Tiechiw-Swatow area. William Dean focuses on the Chinese community in Bangkok. In order to meet the needs of foreigners to learn Chinese and the needs of young Chinese to learn English, William Dean compiled a collection of his manuscripts on learning Chinese (William Dean, 1841: Preface), including 4 sheets and 48 pages (Alexander Wylie, 2011: 92). In 1841, in Siam Bangkok, William Dean published the First Lessons in the Tiechiw Dialect which is the first literature of Teochew dialect in Romanization. It was also the first textbook on Teochew dialect written by western missionaries.

In 1847, Josiah Goddard wrote and published A Chinese and English Vocabulary in the Tiechiu Dialect with 248 pages of 8 sheets in Bangkok, which was republished by American Presbyterian Mission Press in 1883.

\subsection{From 1870s to 1911, Period of Specialization of Lexicography in Teochew Dialect}

After the second opium war, missionaries in China were granted the right to live in the mainland, as well as free access to rural areas and the right to preach. With the opening of Swatow treaty port, the Christian cause in Tiechiw-Swatow area ushered in a period of rapid development.

In 1860, American Baptist missionaries William Ashmore and John W. Johnson preached on Mayu island in Swatow, then preached in Dahao Church (Rao Zongyu, 1965: 202). In 1884, W. Ashmore wrote Primary Lessons in Swatow Grammar[colloquial] and published by English Presbyterian Mission Press.

In 1873, American Baptist missionary Adele M. Field came to Swatow Kakchio to establish the Kakchio Bible-Woman School for women, which aims to train local women to become evangelists and bible teachers (Leonard Warren, 2003: xi). It set a precedent for girls' education in eastern Guangdong. That same year, Field established kakumi elementary school in Swatow. In 1878, Field compiled An Index to William Dictionary in the Swatow dialect and the First Lessons in the Swatow Dialect (Leonard Warren, 2003: 73-74). In 1883, she was writing Pronouncing and Defining Dictionary of the Swatow Dialect Arranged According to Syllables and tones, by American Presbyterian Mission Press.

The Presbyterian mission in Tiechiw-Swatow began with William C. Burns. As the mission did not work well, William C. Burns soon returned to Amoy and consulted with the committee, which sent George Smith to Swatow. George Smith established the first Presbyterian mission in Swatow. In 1883, the British Presbyterian missionary William Duffus, put the missionaries Rudolf Lechler's manuscript in 1853 as the foundation, writing the English-Chinese Vocabulary of the Vernacular or Spoken Language of Swatow.

In 1874, Gibson came to Swatow, and in 1875, Gibson went to Amoy to study the transcription of vernacular Chinese pronunciation into Roman characters. Gibson was amazed at how many illiterate women in Amoy could chant Scripture as fluently as the Scots (Edward Band, 1979:44). In the same year, Gibson created Swatow vernacular, the Roman pronunciation of Swatow church. In 1886, Gibson in English Presbyterian Mission Press, has published A Swatow Index to the Syllable Dictionary of Chinese by S. Wells Williams, and to the dictionary of the Vernacular of Amoy by Carstairs Douglas. In 1907, Gibson wrote the Manual of Swatow Vernacular, Part 1.

In 1892, John Steele arrived in Swatow to preach. In 1909, John Steele wrote The Swatow Syllabary with Mandarin Pronunciation, which was published by Shanghai Presbyterian church.

From the 1870s to 1911, apart from the eight dictionaries of Tiechiw-Swatow dialect compiled by missionaries in China and missionaries in Tiechiw-Swatow region, sinologists compiled two dictionaries of Tiechiw-Swatow dialect. In 1877, Giles published the Handbook of the Swatow Dialect with a Vocabulary in Shanghai.

In 1886, the interpreter Lim Hiongseng of Singapore straits settlements compiled A Handbook of the Swatow Vernacular, published by the Koh Yew Hean Press in Singapore. Lim Hiongseng pointed out in the foreword that this dictionary helps Tiechiw-Swatow people learn English and foreigners learn the Tiechiw-Swatow dialect. The first part is the textbook, which consists of 33 lessons. The second part is thesaurus, sorted by English initials and there are English, Roman and Chinese characters contrast.

\section{The Change of Compilation Method and Art of Lexicography in Tiechiw-Swatow Dialect}

During the contact and communication with Tiechiw-Swatow people, missionaries in China gradually recognized the language symbol system of Tiechiw-Swatow dialect, which was characterized by its pronunciation, shape and meaning. On the basis of following the basic principles of lexicography, they compiled textbooks and dictionaries of Tiechiw-Swatow dialects. Its content design, Roman pronunciation scheme and compilation techniques such as word headings and tone annotation have experienced a gradual process of continuous improvement. Compiling a dictionary requires editors to "create" from compilation scheme, style design, corpus preparation, entry selection and 
setting up to dictionary definitions and example sentence selection (Zhang \& Yong, 2007: 93).

\subsection{Changes of Teaching Materials Compilation Techniques in Tiechiw-Swatow Dialect}

The textbooks of Tiechiw-Swatow dialect in the late Qing dynasty showed the characteristics of phased development:

In the early days of Tiechiw-Swatow dictionaries compiled by missionaries in China in the 1840s, the American Baptist church continued to send missionaries to southeast Asia and Hong Kong. As the pastor of the first local Chinese church, William Dean wrote the Tiechiw-Swatow dialect textbook to serve western missionaries learning the Tiechiw-Swatow dialect and the Tiechiw-Swatow people learning English. Its content focuses on learning and using, emphasizing the effectiveness, and at the same time, a large number of Tiechiw-Swatow dialect teaching content related to Christianity appears in the textbook.

In the first stage of the specialization of dictionaries of Tiechiw-Swatow dialects in the 1870s, the textbooks of Tiechiw-Swatow dialects compiled by foreigners showed the characteristics of specialization and systematization. At this stage, the curriculum design of the textbooks in Tiechiw-Swatow dialect was more scientific and standardized, and the content of the curriculum changed from the simple teaching of spoken English to a more comprehensive and comprehensive language learning, and the scope of learning expanded from missionary to Chinese and western businessmen, officials and scholars. The elementary course in Swatow dialect became a compulsory course for students in Kakchio Bible-Woman School and a teaching material for Kakchio Primary school. The textbook attracted many illiterate believers to study (Miss Mag, 1878(10-11):115).

The second stage of the specialization of Tiechiw-Swatow dialects' lexicography is in the 1880s. On the basis of the curriculum design of the first stage, more emphasis was placed on the theorization and specialization of language learning, focusing on the teaching of grammar and becoming a specialized single-subject knowledge textbook for native English speakers. The course design is based on the First Lessons in the Swatow Dialect written by Field. The way to extract Tiechiw-Swatow dialect by western grammar is a very pioneering textbook of Tiechiw-Swatow dialect.

\subsubsection{In the stage of the $1840 \mathrm{~s}$}

Content design: in 1841, William Dean compiled the First Lessons in the Tie-chiw Dialect, which begins with a list of 18 vowel, diphthong and nasal sounds. Its contents are English, Chinese characters and Romanization, the choice of words, phrases and sentences based on everyday language and Christian missionary affairs, and the English interpretation of the first letter order.

There are some mistakes in the Chinese characters in the book. This book mistakenly takes the Chinese word “放尿” correspond to Roman sound "pang sai", the Roman phonetic notation and English interpretation "To go to stool" meaning is the same, all is a “shit", but the Chinese word for “放尿” Roman sound should be [pàng jiē], means for pee (William Dean, 1841: 6, 23 ).

Although the authors did not introduce the difference between literary and colloquial readings, but part of the Roman showed this point. On page 8, the Romanization of the word “讲” in “伊讲怎生么” is /kong/, which is the literary reading in Tiechiw-Swatow dialect. Generally, in Tiechiw-Swatow area the Romanization of “讲” is / káng /, which is the colloquial reading.

Tone-marking: William Dean points out in his foreword that there is no tone-marking of words in this book, only a simple Romanization. Tiechiw-Swatow dialect has eight tones, no phonetic Romanization in the expression is very limited.

Roman pronunciation scheme: at the beginning of creation, there was a lack of reference from relevant materials. There was no rigorous standard for Roman pronunciation. The same initial and final had several spelling schemes. Such as 痛 Thia, 听 T'hia, 体 Toi these three words (William Dean, 1841:18, 21, 22 ) of the initials of the Roman alphabet writing respectively for the/th/、/t'h/和/t/, but actually they have the same pronunciation, in today's IPA (teochiew initials international phonetic alphabet) their writing is $/ \mathrm{t} / \mathrm{h} /$

William Dean failed to distinguish between nasal and Yin-sheng rhymes. For example, the Roman sounds of “痛” and “听” end with a vowel sound in the book, which is Yin-sheng sound. In fact the two words are nasal rhyme, writing respectively as /thiàn/ and $/$ thia $^{\mathrm{n}} /$ in POJ. This book using $\sim$ to distinguish nasal rhyme, such as 五 Gñou, but accounted for only a few, most of the nasal rhyme and Yin-sheng rhyme are not differentiated.

William Dean just use `on vowels to represent the glottal stop / - ? / of entering finals, such as 一 chěk、八 poǐ、节 Chăt etc. He didn't specify the entering finals ending with /-t/, /-p/, and /-k/. 
First Lessons in the Tie-chiw Dialect is the first Tiechiw-Swatow dialect textbook compiled by the western missionaries. This textbook shows rough, lacks the tone mark, the content classification lacks the rule, the roman spelling phonetic symbol sound is not rigorous science and so on. However, this textbook innovates the method of using Romanization as phonetic annotation for Tiechiw-Swatow dialects, and presents the characteristics of oral textbooks. The teaching content focuses on the colloquial learning of phrases, sentences and other colloquial learning, while the content of written language is less.

\subsubsection{In the Stage of the $1870 \mathrm{~s}$}

Field compiled the "First Lessons in the Swatow Dialect" (1878), which is the second textbook of Tiechiw-Swatow Dialect published by western missionaries in Swatow after published First Lessons in the Tie-chiw Dialect 37 years.

Content design: Field provides guidelines for use in the preface, including how to correct pronounce eight tones of Tiechiw-Swatow dialect, aspirates and unaspirated sound, 32 vowels, double vowels, consonants, nasal rhyme and non nasal rhyme, also provides detailed pronunciation practice. It also provides the comparison of counting symbols, written Chinese characters and counting Chinese characters. The text includes two hundred lessons, each lesson sets up 12 words or phrases, and provides the literary and colloquial readings as well as the corresponding English meaning, at the same time using the words listed in each lesson to group words or sentences and comparative with the English meaning. The book also have an index to help readers find the corresponding words in Romanization.

Tone mark: Field gives two kinds of label mark symbol of the tones, one called “四角圈破法” which is a traditional Chinese tone mark---circle or point the four corners of words, the other is create by Field, Yang-ping and Yang-ru use, Yang-shang expressed with ,- 、' ' ' respectively expressed Yang-qu, Yin-shang and Yin-qu.

Romanization scheme: Field's Romanization scheme in this book is more standardized: unlike William Dean's way that a single initial and final correspond to multiple phonetic symbols, the vast majority of phonetic symbols are marked one-to-one. In the First Lessons in the Tie-chiw Dialect, ${ }^{\left.\mathrm{t}^{\mathrm{h}}\right]}$ respectively corresponding to th、 $\mathrm{t}^{\mathrm{t}} \mathrm{h} 、 \mathrm{t}^{\mathrm{t}}$ three phonetic symbol, in this book are only refers to th; In First Lessons in the Tie-chiw Dialect, the polyphonic sound [au] is written as aou for most of the time. In some words, it is written as ow. In this book, it is written as the standard /au/. The compound sound [uai] corresponds to uai and uay in the First Lessons in the Tie-chiw Dialect, but only correspond to uai in this book.

Secondly, this book distinguished the aspirated and unaspirated voices, Yin rhymes and nasal rhymes. First Lessons in the Tie-chiw Dialect didn't distinguish the affricates' aspirated and unaspirated, $/ \mathrm{ts} / \mathrm{and} / \mathrm{ts}^{\mathrm{h}} /$ generally use ch to mark. Field use $\mathrm{h}$ to express aspirated, /ts/ and $/ \mathrm{ts}^{\mathrm{h} /}$ respectively are written as c and ch; the paper provides a comparative study of aspirated and unaspirated sounds, such as 角 kak and 壳 khak, 卒 cut and 出 chut. For the nasalization phenomenon of Yin-sheng rhyme, this book used a way that add ${ }^{\mathrm{n}}$ at the end of the syllable to distinguish, such as 山 suan 、鞍 ua ${ }^{\mathrm{n}}$ 、章 cie ${ }^{\mathrm{n}}$, etc. (Field, 1878: 7), Field even listed part of the aspirated nasal rhyme, such as 坑 $\mathrm{khe}^{\mathrm{n}}$ 、鲜 $\mathrm{chi}^{\mathrm{n}}$, etc;

First Lessons in the Swatow Dialect has the characteristic of comprehensive teaching material: its content is more complete, teaching design is more scientific. Not only the teaching content increases, the book reaches 427 pages, but also the text of the two hundred lectures follows the rules from simple to difficult, and the quantification of words and phrases. The introduction and comparison of tones, aspirated and unaspirated notes, nasal rhymes, etc. in the previous article will help beginners to learn better.

In contrast, Handbook of the Swatow Dialect with a Vocabulary by Giles is a comparison of English and Swatow words and phrases. The book is only 57 pages, simple and rough, and the Roman pronunciation scheme is not yet mature.

\subsubsection{In the Stage of the1880s}

Content design: Primary Lessons in Swatow Grammar [Colloquial] by William Ashmore (1884) differs from two previous textbooks that it is written entirely in English without any Chinese characters. William Ashmore used four pages to explain the grammar of Tiechiw-Swatow dialect in detail, which is not only a precedent for western missionaries to write textbooks of Tiechiw-Swatow dialect, but also an example for western missionaries to compile literature of Tiechiw-Swatow dialect. William Ashmore used western grammar to classify and explain the Tiechiw-Swatow dialects. He mentioned that there is no fixed grammatical rule in Tiechiw-Swatow dialects, so this book tries to compare it to the closest western grammar. William Ashmore classifies words according to western grammars such as numeral, adverb and pronoun, and compares them with Romanization and English words, but without definitions or examples. 
William Ashmore discussed the differences of dialects in Tiechiw-Swatow area. He pointed out that $\mathrm{T}^{\text {nieine dialect }}$ change the most, and list the finals of $\mathrm{T}^{\mathrm{n}}{ }^{\mathrm{ei}} \mathrm{i}^{\mathrm{e}}$ dialect that changed the most: $\mathrm{e} 、 \mathrm{u} 、 \mathrm{oi}^{\mathrm{n}} 、 \mathrm{au} 、 \mathrm{u} 、 \mathrm{a} 、 \mathrm{io} 、 \mathrm{i}$; It also lists commonly mix initials in phrases such as 1 and $n 、 b$ and $m 、-t$ and $-k$, ch and ts.

Tonal notation: this book follows the tonal notation of First Lessons in the Swatow Dialect which compiled by Field. It adds the example characters and eight tones for compare and also provided Quan-po method and phonetic comparison diagram.

Roman sound plan: William followed the phonetic transcription that add ${ }^{\mathrm{n}}$ at the end of the Roman alphabet to mark the nasal rhyme, and plus $\mathrm{h}$ to distinguish aspirates and unaspirated sound; The tone of Tiechiw-Swatow dialect will change in some phrases, which is not described in detail by William Ashmore. You can have a deep understanding by referring to the Pronouncing and Defining Dictionary of the Swatow Dialect Arranged According to Syllables and tones compiled by Field. Vowels and consonants in the phonetic transcription is the same, the difference mainly focused on the initials, such as /ts/ and /ts ${ }^{\mathrm{h}} /$ in the First Lessons in the Swatow Dialect express as $\mathrm{c}$ and ch, but in this book is ch and chh.

Compared with previous two textbooks, this book has made progress in grammar teaching, and it has a more in-depth scientific approach to language learning. Contents are classified according to grammar. The introduction to the special changes of Tiechiw-Swatow dialects in $\mathrm{T}^{\mathrm{n}} \mathrm{ei}^{\mathrm{n}} \mathrm{e}$ area and the pronunciation guidance are helpful for beginners to master the differences of Tiechiw-Swatow dialects. In this paper, the description of the mixing of /-t/ and $/-\mathrm{k} /$ will provide literature materials for the follow-up research on the evolution of Tiechiw-Swatow dialect. Because the book is written only in English and Romanization, the audience is limited to native English speakers, not as wide as the audience of the previous two textbooks; Secondly, text of this book only uses Romanization and English interpretation for comparison, English interpretation is relatively short, not like First Lessons in the Swatow Dialect which provide examples.

Lim Hiongseng's A Handbook of the Swatow Vernacular, which has a mature Roman pronunciation scheme, and has notes for tone, nasal rhyme and intonation rhyme, etc. The second part of the dictionary content is less, because the author only selected important words.

\subsection{Historical Changes of Tiechiw-Swatow Lexicography}

A total of 8 dictionaries of Tiechiw-Swatow dialects compiled by western missionaries in the late Qing dynasty were concentrated in three stages, and the compilation techniques showed a trend of phased development:

\subsubsection{In the Stage of the1840s}

In the first stage of Tiechiw-Swatow dialect lexicography, the Roman pronunciation was used as the ranking. The pronunciation of the words of the same Roman pronunciation was distinguished by Quan-po method (circle breaking). Each character has an equivalent and comprehensive English translation, and the length is compact. Its disadvantages are the lack of grammar, syntax and usage guidelines, and literary and colloquial readings.

In 1847, Josiah Goddard wrote A Chinese and English Vocabulary in the Tie-Chiu Dialect, which was published in Bangkok. This dictionary is the first Tiechiw-Swatow dialect dictionary compiled by western missionaries.

Content design: the dictionary is based on the purpose of learning Tiechiw-Swatow dialect for western missionaries. The content is 237 pages long and has the framework of a modern dictionary: each page is marked with the Romanization contained in this page. The content is sorted from a-y according to the initial letter of the vowel of Tiechiw-Swatow dialect, and the same words in Romanization are grouped into one section. Josiah Goddard uses Quan-po method which is the traditional Chinese looping method of marking the four corners of Chinese characters to distinguish the pronunciation of Chinese characters that are grouped into sections, each with a short English annotation. At the end of the text, Josiah Goddard attached a Chinese character list sorted by strokes, according to which readers can find Chinese characters in the character list. Josiah Goddard annotated every word in English, but the text was too short and lacked examples.

Roman sound plan: Josiah Goddard mark 17 vowel, double vowel and consonant sounds with phonetic symbols, and indicate how changes in pronunciation, rather like William Dean only used "abrupt" in the First Lessons in the Tie-chiw Dialect to identify the duration, at the same time, the pronunciation in different accents in teochew comparing different vowels. In the introduction, the eight tones of Tiechiw-Swatow dialect are introduced and annotated in a long length, and the traditional Quan-po method of breaking the circle is adopted to compare the eight tones of ancient Chinese.

In terms of marking, Josiah Goddrd uses the method marked " " to distinguish between the aspirated and the 
unaspirated, such as to 去 kù; the annotation " $n$ " in front of the vowel distinguish the Yin-sheng rhyme and nasal rhyme, such as 上 $\mathrm{ch}^{\mathrm{n}} \mathrm{ie}$ 、平 $\mathrm{p}^{\mathrm{n}}$; Tonality has improved, using the traditional Chinese method called Quan-po method, and the First Lessons in the Tie-chiw Dialect does not mark tones at all.

Chinese Comparison: classified according to the Roman alphabet words means not rigorous, the different pronunciation of the word may be classified as the same Romanization category, “渣” in page 5 /tsa/ is a affricate before to the tip of the tongue, clearly different from“柴”/tshâ/ which is a aspirated affricate before to the tip of the tongue, but it classified as the Romanization categories of 柴 /chá/.

The A Chinese and English Vocabulary in the Tie-Chiu Dialect is the first dictionary to introduce the phenomenon of literary and colloquial readings in Tiechiw-Swatow dialect, and marking the pronunciation of characters with literary and colloquial readings.

\subsubsection{In the Stage of the 1870s-1880s}

In the second stage, the trend of dictionary specialization is reflected in the target audience positioning and content design of dictionaries. Pronouncing and Defining Dictionary of the Swatow Dialect Arranged According to Syllables and tones is a bilingual dictionary, which takes Tiechiw-Swatow dialect as the source language and compares the English definitions. It is mainly for readers of Tiechiw-Swatow dialect as their mother tongue or learning object to consult the definitions. English-Chinese Vocabulary of the Vernacular or Spoken Language of Swatow is a monolingual dictionary, which compares English as the source language with Tiechiw-Swatow Roman pronunciation, mainly for readers who use English as their mother tongue or a second language to learn the Tiechiw-Swatow dialect. An Index to William Dictionary in the Swatow dialect and A Swatow Index to the Syllable Dictionary of Chinese by S. Wells Williams, and to the dictionary of the Vernacular of Amoy by Carstairs Douglas, help the reader in the Chinese-English dictionary of Vernacular or Spoken Language of Amoy, with the principal variations of the Chang chew and Chin chew dialects and A Syllable Dictionary of Chinese query against the detailed English interpretation.

The thesauri of this stage is based on the previous works compiled or quoted or indexed, providing instructions on how to pronounce tones, initials, finals, etc. Its common shortcoming is that it does not provide grammatical explanation, because it is difficult to find an accurate English definition and Chinese original word for many colloquial sayings and slang of Tiechiw-Swatow dialect, so descriptive English definition and Tiechiw-Swatow dialect xunreadable (训读字) word appear in the dictionary.

In 1878, Field also published An Index to William Dictionary in the Swatow Dialect, a work of Tiechiw-Swatow Dialect.

This dictionary is a dialect index for A Syllabic Dictionary of the Chinese Language compiled by Samuel Wells Williams. The dictionary, which contains 12,527 Chinese characters, took 14 years to compile and is based on Beijing dialect and English definitions. Field's index was prepared for her later compilation Pronouncing and Defining Dictionary of the Swatow Dialect Arranged According to Syllables and Tones by mark the Roman characters of Tiechiw-Swatow dialects and comparing the contents of the dictionary.

In 1883, Field's compilation Pronouncing and Defining Dictionary of the Swatow Dialect Arranged According to Syllables and Tones and William Duffus's compilation English-Chinese Vocabulary of the Vernacular or Spoken Language of Swatow published one after the other.

Pronouncing and Defining Dictionary of the Swatow Dialect Arranged According to Syllables and Tones

Field visited Tiechiw-Swatow for 4 years and compiled a compilation of 5442 words. Field stresses that Romanization can only be pronounced in close proximity to the Tiechiw-Swatow dialect but not in exactly the same way. There are many accents in Tiechiw-Swatow dialect, and the Romanization of the dictionary is based on the accent of chaozhou prefectural city. At the beginning of the dictionary, Field continued to use part of her First Lessons in the Swatow Dialect: it introduced the eight tones of Tiechiw-Swatow dialect, but it was more detailed than First Lessons in the Swatow Dialect, forming a comparison of the three forms of Quan-po method, intonation and pronunciation diagram. Attach a list of vowel sounds and consonants, contrast and practice between aspirated and unaspirated sounds, and nasal and non-nasal sounds.

Content design: the text of the dictionary is arranged according to the chao-shan pronunciation of Chinese characters. The text is arranged according to Chinese characters, Romanization and English definitions. Field also provides a byword table, which can be indexed in the dictionary and the A Syllabic Dictionary of the Chinese Language. In addition to the theme of different, different from the First Lessons in the Swatow Dialect is the text typesetting in this dictionary. Whether in Chinese or English, First Lessons in the Swatow Dialect follows the western typesetting 
method, that is, from left to right, while this dictionary adopts the traditional typesetting method of China, from top to bottom, from right to left.

Roman sound plan: Field, points out that some phrases, in some cases, will change the original tone, she list phrase pronunciation table, such as the Yin-ping level tone in “妖精” change to io-cia ${ }^{n}$, Yin-ru level tone in “切要” change to chiet-io.

Chinese Comparison: This dictionary exists partial xunreading (训读) word use of unreasonable, [tàn] correspond to Chinese character 讲 káng, which is a xunreading word to make a better understanding of the word's meaning for western missionaries. But this sound in Tiechiw-Swatow dialect commonly us idiomatic word “呾” to contrast, the two words' pronunciation is quite different, so choose “讲” to be a xunreading is not appropriate (Field, 1883: 518).

\section{English-Chinese Vocabulary of the Vernacular or Spoken Language of Swatow}

Content design: this book is based on the manuscript written by the missionary Rudolf Lechler before 1853, which was compiled to help western missionaries learn Tiechiw-Swatow dialect. Therefore, there are no Chinese characters in the book. The full text is in Romanization and English, with the first and last two words in the header of each page. William Duffus listed 23 vowels, diphthongs and consonants in the dictionary, and defined the pronunciation by comparing them with English words and adding and quoting some descriptive words (William Duffus,1883: CONSONANTS). When marking eight tones, William Duffus cited the corresponding tone of Romanization for assistance in learning.

Roman sound plan: William Duffus use Josiah Goddard's way that add ${ }^{n}$ to distinguish nasal rhyme, but the difference is Josiah Goddard add " before vowel, William Duffus followed Adele M. Filed and William Ashmore's way, which add ${ }^{n}$ at the top right corner of the Romanization system to distinguish the nasal rhyme, unified annotation in the Roman alphabet in the top right corner of the way to represent the nasal rhyme.

William Duffus's marking phonetic system is similar to that of Field. On the note of aspirated and unaspirated sound, different from Josiah Goddard's way that use "“" to distinguish aspirated and unaspirated sound, William Duffus and Field both marked "h" to distinguish. But unlike Field, William Duffus use ts and tsh to express [ts] and [ts ${ }^{\mathrm{h}}$ of affricate before the tip of the tongue, and Field use c and ch; For [dz], William Duffus mark as z, and Field mark as j; Tones' annotation is basically the same, the difference is that for Yang-qu rhyme, Field note as ${ }^{-}$, William Duffus note

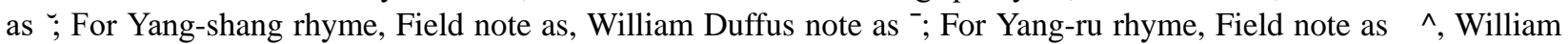
Duffus note as' .

Chinese characters: the text is sorted according to the first letter of English words, regardless of part of speech. The difference from the previous dictionary is that William Duffus listed a number of words for each Tiechiw-Swatow dialect to contrast, not just a simple Romanization contrast text literary and colloquial readings. For example, for contrasting the Tiechiw-Swatow dialect Romanization of English word "a", William Duffus listed “一个”, “一件”.

A Swatow Index to the Syllable Dictionary of Chinese by S. Wells Williams, and to the Dictionary of the Vernacular of Amoy by Carstairs Douglas

In 1886, Gibson compiled A Swatow Index to the Syllable Dictionary of Chinese by S. Wells Williams, and to the Dictionary of the Vernacular of Amoy by Carstairs Douglas, which published in Swatow English Presbyterian Mission Press. This dictionary is a reference and comparison of the Tiechiw-Swatow dialacet in A Syllabic Dictionary of the Chinese Language and Chinese-English dictionary of Vernacular or Spoken Language of Amoy, with the principal variations of the Chang chew and Chin chew dialects. As early as 1875, Gibson created a set of Swatow vernacular characters in Swatow, also called Swatow church Roman characters. The method of marking vowels is used to distinguish tones, and " $\mathrm{h}$ " is used to distinguish aspirated and unaspirated sounds.

\subsubsection{In the Stage of the 1900s}

In the third stage of early 20th century, fewer dictionaries were compiled. Dictionaries in this period were based on predecessors' dictionaries, and their definitions were more accurate, more in line with the basic principles of lexicographic definitions and the principles of feasible compilation (Sindney I. Landau, 2005:169). The Swatow Syllabary with Mandarin Pronunciations set is a comparison between Tiechiw-Swatow slang as the source language and Tiechiw-Swatow orthotonism for readers to learn the orthotonism of Tiechiw-Swatow.

In 1907, Gibson compiled the Manual of Swatow Vernacular, Part 1 published in Swatow by Swatow English Presbyterian Mission Press, which has 143 pages book. The book follows the Roman character created by Gibson in 1875. Throughout the 19th century, this set of Roman fonts had a wide and far-reaching impact. William Duffus, William Ashmore and other missionaries compiled the Tiechiw-Swatow dialect works all used this font. 
In 1909, The Swatow Syllabary with Mandarin Pronunciations, compiled by John Steele, was published by American Presbyterian Mission Press. This book aims to help people learn the original pronunciation and orthography of chaozhou dialect. It uses the word identification method of "at the top of each line, indicating the original pronunciation of chaozhou, noting the central orthography, noting the other pronunciation of chaozhou on the right, duplicating the branches, and indicating the characters (于每行之首, 注明潮州本音, 中央注准定正音, 右边又注 潮州别音, 分行迭记, 字字注明)" to compare the original pronunciation with the orthography of chaozhou dialect, hence the name The Swatow Syllabary with Mandarin Pronunciations. The book is also attached to the "Chaozhou Vernacular Learning (潮州白话字初学)”。

\section{Conclusion}

Western missionaries' dictionaries of Tiechiw-Swatow dialect were compiled to facilitate missionary activities and spread western culture. Dictionaries of Tiechiw-Swatow dialect as the source language were compiled on the purpose of educating and cultivating local missionaries of Tiechiw-Swatow. Missionary activities were prohibited in Tiechiw-Swatow before the second opium war, and there was a large population of Tiechiw-Swatow people in southeast Asia The earliest dictionaries of Tiechiw-Swatow dialect were published in southeast Asia. At the same time, there are few missionaries who have a good command of Tiechiw-Swatow dialect, so it is very important to compile dictionaries. Although the textbooks and dictionaries of Tiechiw-Swatow dialect compiled by missionaries at this stage were rough, they had already had the prototype of dialect textbooks and dictionaries. In 1883, American Presbyterian Mission Press republished the A Chinese and English Vocabulary in the Tie-Chiu Dialect, which fully demonstrated its practicability.

The writing of Tiechiw-Swatow dialect dictionaries was born in the 1870s and 1880s. After the second opium war, Swatow was forced to open as a treaty port, and missionaries in China gained the freedom to preach and set up a mission station in Swatow. The Tiechiw-Swatow dialect dictionaries published at this stage were all titled "Swatow dialect". In fact, these dictionaries did not all use Swatow dialect, but mixed with the pronunciation of Chaozhou, Swatow, Chenghai and other places. The schemes adopted for tone marking, Roman word scheme, content classification and marking of nasal rhyme into rhyme are similar, with richer and more complete contents. There are not only simple comparative translation, but also grammatical and syntactic interpretation. At the beginning of the 20th century, only two dictionaries were published and the Tiechiw-Swatow dialect of the Roman sound getting increasingly mature.

The compilation practice of Tiechiw-Swatow dialect dictionaries and progress of compilation techniques by missionaries in China according to their own learning and cognitive experience of Tiechiw-Swatow dialect, enriched and developed the western missionaries in China's innovation methods of Chinese dialect phonetic Romanization---the origin of the mandarin Chinese and the Latin Romanized Chinese characters. It had a great influence on the movement of Chinese phonology among Chinese people in the late Qing dynasty. In 1868, the English-Chinese bilingual dictionary compiled by Kuang Qizhao was published by the Chinese Printing Bureau (Hong Kong). It is the only Chinese-foreign bilingual dictionary compiled by Chinese people in the 19th century. In 1913, Zhang Shizhen compiled the Chao-sheng 15 sounds, which was the first dictionary compiled by Tiechiw-Swatow natives. The English-Chinese bilingual dictionary or Tiechiw-Swatow dialect dictionary compiled by Chinese people basically followed the Romanization scheme of western missionaries' in the late Qing dynasty.

The activities of compiling dictionaries in Chinese dialect carried out by late Qing missionaries in China strongly promoted the local literacy rate and the ability of the believers and the public to receive information. Missionaries used Romanization to compile dictionaries of Tiechiw-Swatow dialect to help illiterate believers in Tiechiw-Swatow rural areas master the ability to read in a short period of time, so that they could spell the bible and other Christian works according to Romanization when they could not read. In rural China in the late Qing dynasty, literacy became a symbol of power and status, and scholars were respected by the society. The missionaries' compilation of the Tiechiw-Swatow dialect's Roman pronunciation enabled Tiechiw-Swatow believers to acquire the ability to read in a short period of time, thus greatly benefiting their social status (Joseph Tse-Hei Lee, 2013:86-89). Christians learn western medicine, mathematics and other subjects through dictionaries of Tiechiw-Swatow dialect. Lin Qi, who live in Yanzao village of Chenghai district, send his children to Swatow Presbyterian school to receive education, the Lins' cooperation with Presbyterian missionaries helped them grow into a prominent Christian elite (Joseph Tse-Hei Lee, 2010: 85-86).

In the late Qing dynasty, western missionaries compiled dictionaries of Chinese dialects and formed a unique cultural landscape in modern China. Dictionaries of Tiechiw-Swatow dialects not only reflect the changes of Tiechiw-Swatow dialects in modern times, but also reflect the interweaving and merging of "tradition" and "western" 
in modern Chinese local society, which had a profound influence on the overseas spread of Tiechiw-Swatow dialects and regional culture in modern times.

\section{Acknowledgement}

This paper is sponsored by the general project---Cross Cultural Communication Study on Translation of Peking Gazette (15BXW005) supported by National Philosophy and Social Science Foundation, and the Major Project-Translation and Research on the Sinology Literature from the English Periodical Press in China During Late Qing Dynasty and the First Half of $20^{\text {th }}$ Century（19JDZD04） supported by Guangdong University of Foreign Studies.

\section{References}

Adele, M. F. (1878). First Lessons in the Swatow Dialect. Swatow: Swatow Printing Office Company, pp. 7.

Adele, M. F. (1883). Pronouncing and Defining Dictionary of the Swatow Dialect arranged according to syllables and tones. Shanghai: American Presbyterian Mission Press, pp. 518.

Alexander, W. (2011). Memorials of Protestant Missionaries to the Chinese: Giving a List of their Publications and Obituary Notices of the Deceased (Chinese edit.). Guangxi: Guangxi Normal University Press, pp. 9-299.

Dictionary Compilation and Publication in Late Qing Dynasty. Modern Chinese History Studies (No.1, pp. 94). Beijing: Institute of Modern History CASS.

Edward, B. (1979).The History of the English Presbyterian Mission 1847-1947 Swatow. Hong Kong: Hong Kong Swatow Christian Mission, pp. 44.

Hu, W. Q. (2001). A Study of the Modern Activities of Protestant Missions in Tiechiw-Swatow area.Study of Christianity, 2, 337-358. Beijing: Institute of World Religion CASS.

Jennifer, W. C. (1975). Fields for the Sea: Chinese junk trade with Siam during the Eighteenth and the early Nineteenth century. Ithaca: Cornell University Press, pp. 19.

Jessie, G. L. (1990). The Grand Illusion: Karl Gützlaff and Popularization of China Missions in the United States during the 1830s. Patricia Neils. United States Attitudes and Policies toward China. Armonk: ME SHARPE, pp. 46-77.

Joseph, T. H. L. (2010). The Bible and The Gun: Christianity in South China (1860-1900). Beijing: China Social Sciences Press, pp. 37-195.

Joseph, T. H. L. (2013). Chuan (Preaching): The Evangelistic Mode of Conversion. Richard Fox Young, Jonathan A. Seitz. Asia in the Making of Christianity: Conversion, Agency and Indigeneity, 1600s to the Present. Boston: Brill, pp. 86-89.

Lai, L. S. (1997).The Journal of Hong Kong. Guangzhou: Jinan University Press, pp. 56-66.

Leonard, W. (2003). Adele Marion Fielde: Feminist, Social Activist, Scientist. London and New York: Routledge, Francis \& Tailor Group.

Milne. (1818, August). The Indo-Chinese Gleaner (Vol. 1, No.5, pp. 170-176). Malacca: Printed at the Mission Press.

Miss Mag. (1878). Helps for Learning Chinese. The Heathen Woman's Friend (Vol.10-11, pp. 115).

Mrs. Morrison. (2004). Memoirs of the Life and the Labors of Robert Morrison (Chinese edit.). Guilin: Guangxi Normal University Press.

Rao, Z. Y. (1965). Tiechiw Chorography.Hong Kong: Loonmen Bookstore, pp. 202.

Sindney, I. L. (2005). The Art and Craft of Lexicography. Beijing: The Commercial Press, pp. 169.

Suzanne, W. B., \& John, K. F. (1985). Christianity in China: Early Protestant Missionary Writings. Cambridge: Harvard University Asia Center, pp. 13.

William, D. (1841). First Lessons in the Tie-Chiw Dialect. Bangkok: SIAM, Preface.

William, D. (1841). First Lessons in the Tie-Chiw Dialect. Bankok: SIAM.

William, D. (1883). English-Chinese Vocabulary of the Vernacular or Spoken Language of Swatow. Swatow: English Presbyterian Mission, CONSONANTS.

Yuan, Q. (2013). The Rising and Development of Chinese-English \& English-Chinese.

Zhang, Y. H., \& Yong, H. M. (2007). Current Lexicography. Beijing: The Commercial Press, pp.93. 